\title{
CHILDREN'S RIGHTS IN UKRAINE AS A «NEW AXIOLOGY»OF DEMOCRATIC DEVELOPMENT IN THE CONTEXT OF GLOBALIZATION CHALLENGES
}

\author{
Natalia Stepanenko 1 \\ ${ }^{1}$ Senior Lecturer of the Department of Foreign Languages and Special Language Preparation, Postgraduate \\ student, KROK University, Kyiv, Ukraine, e-mail: nataliasv@krok.edu.ua, ORCID: https://orcid.org/0000- \\ 0001-6216-2206
}

Abstract. Global democracy as a relatively new phenomenon, introduced by the processes of globalization, embodies the formation and implementation of a universal system of human values. Every child, as the most valuable treasure of the state, must grow up in peace and security. However, unfortunately, despite the efforts of most countries in the world, children remain the primary targets of systemic discrimination, which is especially acute in crisis situations, in particular, minors are the main victims of modern armed conflicts: they are involved in fighting, they die as a result of bombing and shelling or are blown up by mines.

The article considers the legal issues of children under the conditions of military aggression in the occupied territories of Ukraine, analyzes how the state protects children victims of hybrid warfare, the involvement of minors in hostilities by the so-called Donetsk and Luhansk "people's republics», outlines prospects for improving Ukrainian legislation with regard to minors, and proposes to criminalize the involvement of children in hostilities and armed conflict.

Keywords: children's rights, armed conflict, hybrid warfare, axiology, protection of children's rights, a child affected by hostilities and armed conflicts, children-combatants, national legislation.

JEL Classification: K15, K30, K40

Formulas: 0; fig.: 0; tabl.: 0; bibl.: 16

Introduction. Today in Ukraine there is an axiological revolution associated with the revision of basic values of life, the formation of a new understanding of the world and human place under the influence of a number of global factors that exacerbate social confrontation, unrestrained economic race, which does not take into account the limited resources of the planet and opportunities for survival. Issues related to the consideration of values are highly diverse. However, the most important value of humanity is children, their health and safety, because they are the future of any state.

The importance and urgency of the article stem from the fact that the armed conflict in eastern Ukraine, which has lasted for seven years, has worsened the situation in areas where Ukraine has made substantial progress and aggravated the difficulties that have yet to be resolved. The Russian Federation is actively involving all means and methods of waging a hybrid war against Ukraine, in which children, the most essential future value, suffer the most. As a result, it is critical to research this issue. There are both theoretical and practical reasons for this. The study of the main categories and provisions of the legal status of child victims enshrined in Ukrainian law has theoretical significance, while practical interest stems from the need to improve relevant law enforcement and government bodies and structures to ensure the rights and needs of children affected by the Donbass hybrid war.

Literature Review. The issue of protection of children's rights during the war in eastern Ukraine has received little attention both in Ukraine and abroad. Among domestic scientists this issue was studied by: L. Volynets, V. Denysov, O. 
Kochemyrovska, A. Lazorenko, H. Mazur, N. Opolska and others. From the standpoint of international law, these issues were studied by N.O. Filipska and O.Yu. Zadniprovska. Among the foreign authors, as a rule, there are representatives of international and regional organizations concerned with the protection of children's rights in armed conflicts. At the same time, there are currently no special studies that comprehensively research the issue regarding the protection of children in a hybrid war in Ukraine.

Our state was not at all prepared to participate in the military struggle, particularly in terms of legislation, which resulted in numerous challenges and disagreements. During the seven years of armed conflict in Ukraine, of course, much has been done by government officials and NGOs to improve the conditions for children who have experienced this terrible event, and legislation has been amended. In the face of the current circumstances, however, there is no comprehensive method in Ukraine that would protect and fully guarantee the rights of a child who has been subjected to armed attack. Unfortunately, most issues are resolved by volunteers, non-governmental groups, and humanitarian organizations. The children were on the verge of new challenges. A number of global issues remain unresolved.

Aim. Children living in the perilous areas of eastern Ukraine, whose lives have been disrupted by the war, require special care and protection today. Based on the current level of research on the aforementioned topic, there is an urgent need to investigate a critical issue for Ukraine: the preservation of children's rights and interests as the state's most essential value in the face of globalization difficulties.

It is vital to conceptualize and examine the rights of children who have been affected by the armed conflict in Ukraine. Simultaneously, it is necessary to determine the circumstances and consequences of using children and adolescents as soldiers in the so-called «people's republics» of Donetsk and Luhansk, as well as to create measures to modify existing legislation to prevent and prosecute this criminal activity.

Methods. To clarify the essence of correctional work, preference was given to such general scientific methods as historical-legal, system-structural and scientific generalization.

Results. Children, like adults, are subjected to complete disruptions of the natural order of things during wartime. Every day, children in eastern Ukraine are attacked, injured, forced to participate in battles, used as human shields, lose their homes, schooling, and medical treatment, and are in constant danger. Everything, from values to daily behaviors, must be rebuilt. Everything you've done previously has the potential to alter. Children, on the other hand, continue to live in conflict: they communicate with their families, make friends, and attend school.

To ensure that Ukraine's children have a carefree upbringing, the military in the east avoids no dangers regarding their health, often risking their lives in the fight for the country's future. If little Ukrainians can comfortably grow and develop, go to school, and dream of new toys in a peaceful territory, then children who have been forced to live in an area of armed conflict for seven years have never known a 
carefree happy childhood, and their only wish is to grow up healthy and wait for the day when it's all over.

The highest social value in Ukraine is an individual, his life and health, honor and dignity, inviolability and security, according to the Ukrainian Constitution (Article 3) [1].

In 1991, Ukraine ratified the United Nations Convention on the Rights of the Child, pledging to implement the protection and promotion of children's rights at the state level. Children have public, political, social, cultural, and economic rights, according to the United Nations Convention on the Rights of the Child [2].

The right to life of a child has societal worth and is a foundation for all other rights. The biggest hazard to human life is war. Any armed war is inevitably accompanied by the dissolution of families, the disintegration of citizens, the rupture of the "social fabric» the destruction of support systems, and the destruction of medical services, according to experience. Children and adolescents (aged 0 to 18) are particularly vulnerable in this situation.

Minors are deprived of a quiet childhood during conflicts, and they suffer both immediate and long-term impacts of hostilities. About two million children have died as a result of the last decade's hostilities (not only from fighting, but also from malnutrition and disease caused or exacerbated by the conflict), and six more have been maimed; approximately 20 million children have become displaced or refugees, and about a million have been orphaned. It is unknown how many children are kidnapped, sold, or sexually exploited; girls and youngsters of both sexes who have been separated from their family are especially vulnerable [3].

According to the Office of the United Nations High Commissioner for Human Rights, seven children have become victims of shelling and damage from mines and explosive devices in eastern Ukraine since the beginning of 2021, four of them have died. During the armed fighting last year, ten children were injured. Between April 14, 2014 and April 30, 2021, there were 152 documented cases of children dying as a result of the conflict in eastern Ukraine (102 boys and 50 girls). 190 youngsters were injured as a result of mine mishaps, the handling of hazardous remains of war, and explosions at military depots. 44 children ( 42 boys and two girls) perished, while 146 others were injured (120 boys and 26 girls).

We consider how the state protects the most vulnerable members of society: children who have been victims of this heinous war. The passage of the Law of Ukraine «On Amendments to Certain Laws of Ukraine on Strengthening Social Protection of Children and Supporting Families with Children» of January 26, 2016 No 936-VIII [5] was a significant step forward in protecting the rights of children in war zones and armed conflicts. This document intends to strengthen Ukraine's system for safeguarding children's rights by improving decision-making structures and procedures to protect children at their residence, support families with children in challenging life conditions, and assist victims of war or armed conflict.

In the Law of Ukraine «On Child Protection» a new category of children appeared - «a child who suffered as a result of hostilities and armed conflicts - a child who as a result of hostilities or armed conflicts received injuries, contusions, maim, 
suffered physical, sexual, psychological violence, was abducted or illegally taken out of Ukraine, involved in military formations or illegally detained, including in captivity [6]. Such a child has the opportunity to obtain the status of a child affected by hostilities and armed conflict. A child can acquire such a status, according to the approved Resolution of the Cabinet of Ministers of Ukraine № 268 05.04.2017 «Procedure for granting the status of a child affected by hostilities and armed conflicts». Unfortunately, it became possible to obtain the status of a child victim as a result of hostilities only in the 6th year of the war - in 2019. Although the relevant resolution was adopted by the government in 2017, during the first year of operation it was difficult to obtain the status due to the imperfect implementation mechanism [7]. According to the operative information of the National Social Service of Ukraine, as of May 30, 2021, the number of children who received the status of a child affected by hostilities and armed conflicts is 66,491. 95 of them received this status due to injuries, contusions, maim [4].

These sobering figures do not properly reflect the magnitude of the suffering endured by children as a result of the long-running armed conflict. It is impossible to estimate the scope of the challenges encountered by children on the other side of the line due to the inability of the state to maintain control over human rights in the temporarily occupied regions.

Unfortunately, the truth about physical and sexual assault against children during the armed conflict is still a secret whether it's due to the inaccessibility of wartorn areas, the victims' silence, or the fear of social rejection or revenge. Victims of violence are frequently denied freedom, reintegration, or legal assistance, despite their desire for justice, rehabilitation, and social inclusion.

Another problem arose with conditionally sentenced children (more than 500 of them in Luhansk and Donetsk regions). They must report regularly to the enforcement service so as not to be imprisoned for violating the probation regime. The issue of exercising the relevant control functions is acute, as the executive services do not work there.

In Ukraine, the category of «child combatants» has emerged, a new group of children with which Ukraine is unfamiliar. These are children who are participating in armed conflicts, according to international law. It should be highlighted that the international community reacts categorically when minors are involved in conflicts. According to Article 4 of the Optional Protocol to the Convention on the Rights of the Child on the Participation of Children in Armed Conflict, ratified by Ukraine's Verkhovna Rada on June 23, 2004, «armed groups other than the state's armed forces should under no circumstances recruit or use in hostilities persons under the age of $18 \gg[8]$.

Despite the ban, militants use children to obtain intelligence, train them to participate in hostilities, and perform ancillary duties. The involvement of children in the armed conflict in eastern Ukraine is due to both children and adults' ignorance of international humanitarian law and Ukrainian juvenile law, both of which forbid minors from participating in any sort of military activity. At the same time, the precarious economic status of young people is a significant factor. According to the 
youngster convicted of participation in an unanticipated armed formation (Article 260 of the Criminal Code of Ukraine), after graduating from high school, he sought unsuccessfully to find work, therefore he joined the criminal group «Donetsk People's Republic» [9]. In many cases, perpetrators of crimes against children face impunity, despite the fact that such offenses are classified as crimes under international human rights law and the Rome Statute of the International Criminal Court. Although almost all states have accepted the Convention on the Rights of the Child, it is not universally implemented. Children suffer disproportionately in armed conflict, and their sufferings are varied and have long-term implications. The effects of armed war on future generations may sow the seeds for violence to resurface or continue. The Additional Protocol to the Convention on the Rights of the Child on the Involvement of Children in Armed Conflict aims to overcome this situation [10].

Today, there are not even approximate statistics on the number of children participating in the armed conflict against Ukraine on the side of the so-called «Donetsk People's Republic» and «Luhansk People's Republic». The only thing that the analysis of the information space of the Russian Federation and the zone of temporary occupation of Luhansk and Donetsk regions shows is that the active involvement of children and adolescents in the ranks of illegal armed groups began in 2014. With regard to such actions against the growing generation, the Prosecutor General's Office of Ukraine has initiated criminal proceedings on the fact of assisting the Russian Federation in preparing children for hostilities. It should be underlined that the occupying Power has no right to compel civilians under protection to serve in its military or auxiliary forces under Articles 47 and 51 of the Geneva Convention relating to the Protection of Civilian Persons in Time of War of 12 August 1949 [11].

In occupied Donetsk and Luhansk, teenagers are enrolled in the organization «Young Guard - Young Army», which militants of the «Donetsk People's Republic» created by analogy with the military-patriotic organization "Yunarmiia (Young Army)» operating in the Russian Federation under the auspices of the Ministry of Defense. Teenagers swear loyalty to the false republic and the occupiers during the reception. In this sense, children in occupied territory are completely militarized, and they are subjected to not just armed violence but also psychological coercion. According to the head of the Eastern Human Rights Group Vira Yastrebova, children throughout the occupied districts of Donetsk and Luhansk regions are involved in honoring the memory of the fallen militants, in unveiling monuments to members of illegal gangs, actions dedicated to «defenders of Luhansk and Donetsk people's republics», in rallies on the occasion of the so-called Day of the State Flag of the Donetsk People's Republic, actions and flash mobs in honor of the anniversary of the publication by the so-called People's Council of Luhansk People's Republic of the law «On the State Flag of Luhansk People's Republic» [12].

Thus, domestic legislation needs to be improved in terms of establishing both criminal liability for involving minors in hostilities and the responsibility of minors themselves for participating in this type of activity. Article 438 of the Criminal Code of Ukraine «Violation of the laws and customs of war» of Chapter XX «Crimes against peace, security of mankind and international law» is proposed to be 
supplemented with the following phrase: «Ill-treatment of prisoners of war or civilians, involvement of minors in hostilities, sabotage or terrorist acts, expulsion of civilians for forced labor, looting of national property in the occupied territories, use of means of warfare prohibited by international law, other violations of the laws and customs of war provided for by international treaties, the binding nature of which has been approved by the Verkhovna Rada of Ukraine, as well as ordering such actions, shall be punishable by imprisonment for a term of eight to twelve years».

Men who support the so-called self-proclaimed but not recognized Donetsk People's Republic and the Luhansk People's Republic prevent women, particularly those with young children, from leaving the combat zone, according to the UN High Commissioner for Human Rights [13].

The birth registration and juvenile justice systems are on the verge of imploding. The possibility of rising social orphanhood has grown. Adoption of children has been halted, and orphans and youngsters deprived of parental care, temporarily removed for rehabilitation outside the conflict zone, have been denied the right to a family upbringing as a result of an unregulated procedure for placing them in the homes of Ukrainian nationals. In the event of legislative changes, these concerns should be carefully evaluated, and social services should work more diligently to investigate guardians and conduct unexpected inspections.

Children and families who are (were) in a zone of military conflict are a category of people who find themselves in difficult life circumstances, and therefore need support and should expect to receive a list of social services defined by Ukrainian law. At the same time, «being in a zone of hostilities» today is not included in the list of difficult life circumstances, the range of which is defined in Art. 1 of the Law of Ukraine «On Social Services». In fact, this is a new category of people for Ukraine, which significantly increases the number of potential consumers of social services at the place of residence [14].

The scenario might be different if the government provided assistance to families with children. But, regardless of who is our president, the government hasn't done so in seven years. When individuals had to be evacuated from the combat zone, nothing was offered to them in Ukraine's controlled region. As a result, the number of displaced people returning to the combat zone with their children is on the rise. There are impoverished communities in Ukraine with empty buildings where individuals from the fighting zone may be housed, but no one has offered them this option. Only recently have government initiatives been established to assist these families. The issues were taken to the municipal level. The burden was taken mostly by the Kyiv, Dnipro, Zaporizhzhia, Donetsk, and Luhansk regions»[15].

At the same time, the initiative of the President of Ukraine to take measures to accommodate as soon as possible children whose parents (one of the parents) died as a result of injury, contusion or mutilation received in the areas of anti-terrorist operation, established by Presidential Decree № 835/2014 29.10.2014 «On urgent measures to provide additional social guarantees to certain categories of citizens» (paragraph 5, part 1) is a positive step [16]. 
Such children are expected to be placed by establishing custody and care of such children, as well as transfer to foster families, family-type orphanages, and institutions for orphans and children without parental care (unfortunately, the latter contradicts priorities of the state for the development of family forms of education and prevention from 01.01.2014 of placement of children in boarding schools; such a mechanism can be considered only as palliative, temporary).

Discussion. Military actions in eastern Ukraine are a flagrant violation of a child's right to life, health care, education, family upbringing, protection from all types of violence and participation in hostilities and armed conflicts, as well as the child's freedom to choose where he or she lives. As a result, the protection of the rights of Ukrainian children who are actively involved in armed conflict is a worldwide issue that the state should address.

Appropriate ways to improve legislation in the field of ensuring and protecting the rights of the child in Ukraine should be based on an approach that, on the one hand, provides positive consequences for the introduction into law and practice of certain legal norms and standards of other states in this area, and on the other hand, will take into account the traditional, real social and regulatory requirements and needs of Ukrainian society.

Conclusions. The government, parliament, public authorities, local governments, and the public need to make every effort to implement a policy to protect and safeguard Ukrainian children from armed conflict. Ukraine should have a state policy to protect the rights of children affected by the conflict in Donbas. There is a need for a separate, integrated state program for conflict-affected children, where assistance measures should be defined, a specific budget set aside to help these children, and local government actions should be coordinated and advice given on how to deal with these children, so that the current imbalance does not exist. National legislation should be brought in line with the requirements of international legal acts in order to close legislative gaps in the sphere of protection of children's rights in the armed conflict in Ukraine.

\section{References:}

1. Constitution of Ukraine of June 28, 1996. Bulletin of the Verkhovna Rada. 1996.

2. Convention on the Rights of the Child. Collection of current international treaties of Ukraine. 1990. № 1. $205 \mathrm{p}$.

3. EU Guidelines for Children in Armed Conflict. URL: https://www.refworld.org.ru/pdfid/5512c43f6.pdf (date of reference: 07.07.2021)

4. Ukrainian National News Agency «Ukrinform»: website. URL:https://www.ukrinform.ua/rubricato/3258811-vnaslidok-rosijskoi-agresii-v-ukraini-zaginuli-152-ditini-i-se-146-buli-poraneni-oon.html. (date of reference: 01.08.2021)

5. On Amendments to Certain Legislative Acts of Ukraine Concerning Strengthening Social Protection of Children and Supporting Families with Children: Law of Ukraine of January 26, 2016 № 936-VIII. Information of the Verkhovna Rada of Ukraine. 2016. № 10. Art. 99.

6. Law of Ukraine «On Child Protection». The Verkhovna Rada of Ukraine: website. URL: https://zakon.rada.gov.ua/laws/show/2402-14 (date of reference: 07.07.2021)

7. On approval of the Procedure for granting the status of a child affected by hostilities and armed conflicts: Resolution of the Cabinet of Ministers of Ukraine № 268 of April 5, 2017. URL:https://zakon.rada.gov.ua/laws/show/268-2017-D0\%BF\#Text (date of reference: 30.08 .2021 )

8. On Ratification of the Optional Protocol to the Convention on the Rights of the Child on the Involvement of Children in Armed Conflict: Law of Ukraine of 23 June 2004 № 1845-IV website. URL: http://zakon4.rada.gov.ua/laws/show/995_795. (date of reference: 23.08.2021) 
9. Proceedings № 1-kp / 235/256/16, The only unique № 235/9951/15-k,: verdict Krasnoarm. city district. court of Donets. reg. April 20, 2016 URL:http://www.reyestr.court.gov.ua/Review/57287047 (date of reference: 23.02 .2017 )

10. Protecting children's rights in armed conflicts: EU policy and practice. Ukrainian law: website. URL: https://ukrainepravo.com/international_law/european_union_law/iashyfkh-tuav-ekkhyem-ts-ibusmryshnsrchoknkhash-tsokkhyna-k-tuankhyna-zhf/ (date of reference: 07.07.2021)

11. Convention for the Protection of Civilian Persons in Time of War. Geneva, 12 August 1949: Website. URL: https://zakon.rada.gov.ua/laws/show/995_154\#Text (date of reference: 07.07.2021)

12. Mosondz O. Shelling on the way to school and mines in the kitchen-garden. Almost half a million children are suffering from the war in Donbass. ArmyINFORM: website. URL: https://armyinform.com.ua/2021/06/obstrily-po-dorozi-do-shkoly-ta-miny-na-gorodi-majzhe-piv-miljonaditej-strazhdayut-cherez-vijnu-na-donbasi/(date of reference: 07.07.2021)

13. Sexual and gender-based violence in the military conflict in Ukraine. URL: http://women-union.org.ua (date of reference: 07.07.2021)

14. Law of Ukraine «On Social Services» of January 17, 2019 №2671-VIII https://zakon.rada.gov.ua/laws/show/2671-19\#Text (date of reference: 07.07.2021)

15. Pavliukovskyi Ye. Children of Donbass: who will be responsible for the lost childhood? Ukrainian Helsinki Human Rights Union. URL: https://helsinki.org.ua/articles/dity-donbasu-khto-vidpovist-zavtrachene-dytynstvo/ (date of reference: 07.07.2021)

16. On urgent measures to provide additional social guarantees to certain categories of citizens. Decree of the President of Ukraine URL: https://zakon.rada.gov.ua/laws/show/835/2014\#Text (date of reference: 07.07.2021) 